\title{
Effect of oxygen tension on the quantities of procollagenase-activating angiogenic factor present in the developing kitten retina
}

\author{
C M TAYLOR,' J B WEISS,' R D KISSUN,2 AND A GARNER ${ }^{2}$

\begin{abstract}
From the 'Departments of Biochemistry and Rheumatology, University of Manchester Medical School, Stopford Building, Manchester, M13 9PT, and ${ }^{2}$ Department of Pathology, Institute of Ophthalmology, London
\end{abstract}

SUMMARY Maintainence of newborn kittens in an oxygen rich atmosphere followed by a recovery period in a normal atmosphere mimicked the effects of the human disease retrolental fibroplasia. The retinas of such kittens contained significantly raised levels of low molecular weight angiogenic material (as measured by procollagenase activation) when compared with those of a control group of kittens.

It was in 1948 that Michaelson' first postulated the presence of a vasoproliferative or angiogenic factor in retinal tissue undergoing active vascularisation. This concept was then elaborated to include hypoxia as the immediate cause of angiogenic factor release..$^{2-4}$ Thus it was suggested that chronic reduction in blood flow, sufficient to cause metabolic disturbance short of complete necrosis, would provoke the synthesis or activation of a substance able to stimulate the development of new blood vessels. It was reasoned that the substance would be easily soluble, with a molecular size sufficiently small for it to diffuse freely through the ocular tissues. ${ }^{5}$ On entering the vitreous gel the angiogenic substance would accumulate in the essentially stagnant environment and exercise a chemotactic effect on vessels close to the retinal surface. This hypothesis was given indirect support in subsequent years when it was shown that obliteration of ischaemic retina by photocoagulation had a beneficial effect on accompanying neovascularisation of the iris, ${ }^{67}$ it being postulated that the soluble angiogenic factor released by the retina in this situation drained forward into the anterior chamber. Conversely it has been found that vitrectomy and lensectomy, which serve to facilitate the access of retina-derived factors to the iris, increase the risk and severity of iris neovascularisation. ${ }^{78}$

More direct evidence in support of this hypothesis was forthcoming when it was demonstrated that Correspondence to Dr Jacqueline B Weiss, Clinical Sciences Building, Hope Hospital, Eccles Old Road, Salford M6 8HD. retinal extracts, not only promote angiogenesis when introduced into the cornea ${ }^{9}$ and chick chorioallantoic membrane ${ }^{10}$ but contain an angiogenic fraction comparable to the endothelial cell-stimulating angiogenic factor (ESAF) present in certain experimental tumours $^{11} 12$ and arthritic joints. ${ }^{13}$

However, since ESAF is a feature of normal retina $^{10}$ the hypothesis of a hypoxic stimulus to neovascularisation needed modification, to the extent that a quantitative increase of a factor already present had to be envisaged rather than the emergence of a new angiogenic substance. ${ }^{9}$ To test this revised hypothesis demanded an assay system much more quantifiable than those provided by the in-vivo systems previously used. This became possible when it was discovered that ESAF will, among other actions, activate skin fibroblast procollagenase ${ }^{14}$. This allows a quantitative assay for angiogenic activity based on collagen lysis using a radiolabelled substrate.

The relationship between other less specific growth factors which have been detected in ocular fluids and ESAF is discussed. ${ }^{15}$

In this paper we present for the first time evidence that the activity of the low molecular mass angiogenic fraction of ischaemic retina is significantly higher than that of normally perfused retina.

\section{Materials and methods}

Newborn kittens were incubated for a period of 10 days in an atmosphere containing $70-80 \%$ oxygen. 
The kittens were then allowed to recover for a period of 11 days in a normal atmosphere before being killed, when the retina was removed. A control group of kittens were maintained in a normal atmosphere throughout a 21-day period.

The retinas were homogenised for $15 \mathrm{~s}$ at $4^{\circ} \mathrm{C}$ in 50 $\mathrm{mM} \mathrm{NH}_{4} \mathrm{HCO}_{3}$ buffer (pH 7.9) $(1 \mathrm{~m} 1 /$ retina) with a glass Potter-Elvehjem homogeniser. Homogenates were centrifuged at $10000 \mathrm{~g}$ for $1 \mathrm{~h}$ at $4^{\circ} \mathrm{C}$. The supernatant was assayed for protein ${ }^{16}$ and was then subjected to untrafiltration on a YM5 filter membrane (5000 Mr exclusion limit) (Amicon Ltd, England) with 5 volumes of bicarbonate buffer. The ultrafiltrate from single or batched retinas was reduced in volume to $5 \mathrm{ml}$, applied to a Bio-Gel P-2 column $(880 \times 22 \mathrm{~mm})$ (Biorad Laboratories, England), and eluted with a $10 \%(\mathrm{v} / \mathrm{v})$ solution of chromatographically pure propan-2-ol (BDH, England). The material eluting with an apparent molecular mass of between 200 to 800 was pooled and lyophilised.

Assay for procollagenase activating material was performed according to the method of Weiss et al. ${ }^{14}$ Assay results were expressed as $\mu \mathrm{g}$ collagen degraded $/ \mathrm{h} / \mathrm{mg}$ protein in supernatant. Confirmation of the angiogenic activity of the procollagenase activating fraction was obtained by the vitelline plexus test. ${ }^{17}$

\section{Results}

Extracts of both control and oxygen treated retinas gave similar profiles when subjected to Bio-Gel P-2 gel filtration chromatography (not shown). Fraction II (200-800 Mr) from both groups of kitten retinas was found to elicit a positive response when tested on the vitelline plexus (Fig. 1). Activation of procollagenase permitted a quantitative assay of this fraction from both control and oxygen treated retinas (Table 1). It was apparent that the retinas from oxygen treated kittens contained significantly raised levels of low molecular mass procollagenase activating material.

\section{Discussion}

The vaso-obliterative potential of hyperoxia in the context of the kitten retina was first demonstrated in Ashton's laboratory ${ }^{2}$ and is possibly a direct toxic effect by superoxide ions and free radicals on newly formed vascular endothelium. ${ }^{18}$ On return of the kittens to normal air the retinal tissue deprived of its vasculature might be expected to suffer hypoxia and would probably become necrotic were it not for the choroidal component of its nutrition. In this circumstance the retina undergoes revascularisation from residual vessels at the optic disc, the new vessels proliferating not only within the retina but also on its surface. It takes about 10 days before preretinal vessels can be discerned. On the assumption that the emergence of any angiogenic fraction must precede definite vessel growth, the animals were killed at 11 days into the recovery period. The control animals were of the same age.

An important component of the angiogenic process is the destruction of the collagenous extracellular matrix, through which blood vessel growth is to

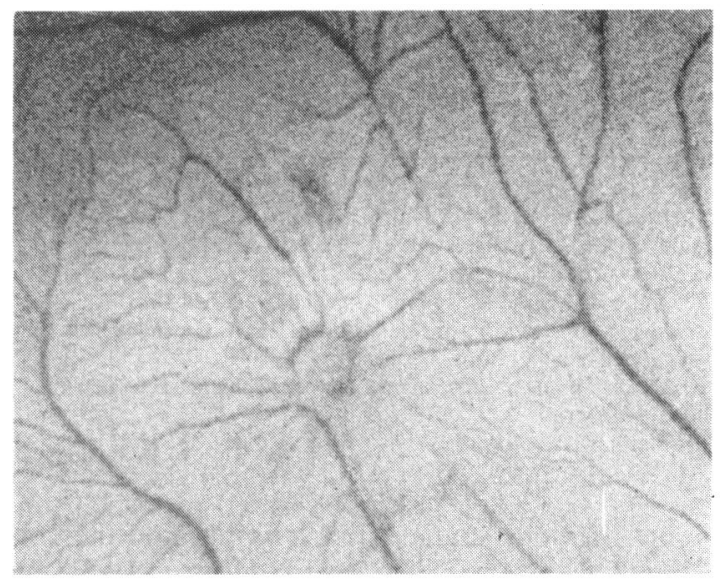

Fig. 1a

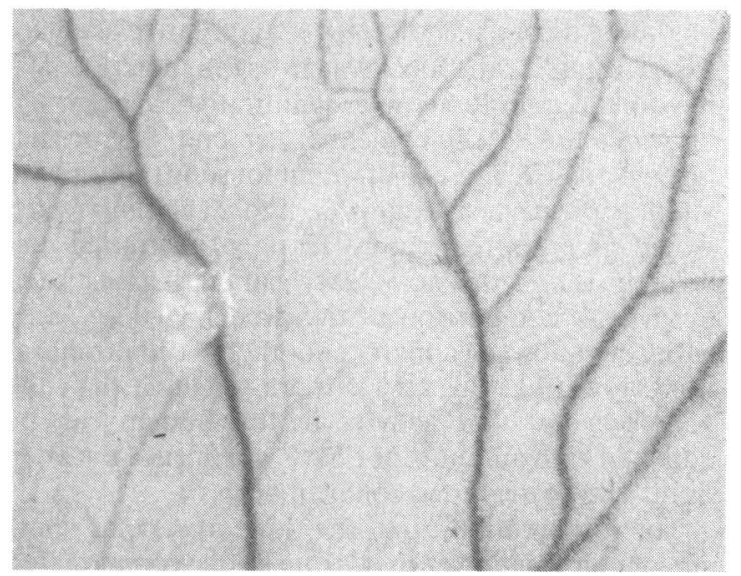

Fig. 1b

Fig. 1a Chick vitelline membranes showing the response to (a) a sample of ESAF derived from kitten retinas applied in a pellet of Elvax polymer, and (b) a control containing no ESAF in a similar pellet. Note the change in the vasculature of the test sample where vessels are drawn into the centre where the pellet has been applied. This directional realignment or reorganisation is probably the first step in angiogenesis. 
Table 1 Activation of procollagenase by retinal $^{2}$ ESAF' derived from normal and oxygen treated kittens

$\mu \mathrm{g}$ collagen degraded/h/mg/protein in supernatant

\begin{tabular}{lll}
\cline { 2 - 3 } Experiment & Oxygen treated & $\begin{array}{l}\text { Normal, non- } \\
\text { oxygen treated }\end{array}$ \\
\hline 1 & 2.93 & 0.79 \\
2 & 5.24 & 0.31 \\
3 & 3.13 & 0.90 \\
4 & 1.11 & $0 \cdot 56$ \\
5 & 2.56 & 0.41 \\
6 & 1.03 & 0.64 \\
7 & 0.476 & 0.321 \\
8 & 1.49 & 0.80 \\
Mean & 2.24 & 0.59 \\
SD & 1.548 & 0.228 \\
p=0.01 & & \\
\hline
\end{tabular}

Note. Experiment 1 was the sum of three pairs of retinas and experiment 2 of six pairs. All other experiments were performed on single retinas. The oxygen treated kittens were exposed to oxygen for 10 days and allowed to recover for 11 days.

*The procollagenase used in the assay had very little intrinsic collagenolytic activity; enzyme without ESAF degraded less than $0.36 \mu \mathrm{g}$ collagen per hour.

†ESAF itself in the absence of procollagenase had no effect on the collagen substrate.

SD=standard deviation

occur. Previous studies ${ }^{11-14}$ have implicated the collagenolytic system in this degradative process. ESAF from all tissue so far examined has proved able to activate fibroblast procollagenase. ${ }^{12}$ This activation has been the basis of a sensitive quantitative assay for ESAF using ${ }^{3} \mathrm{H}$ labelled collagen as the substrate. We have been able to show a quantitative relationship between the vitelline plexus test and the procollagenase assay. The cut-off point for sensitivity on the vitelline plexus test is equivalent to an amount which would give approximately $12 \mu \mathrm{g}$ of degraded collagen $/ \mathrm{h}$. Below this no activity can be demonstrated in vivo. A comparison of the procollagenase assay with activation of capillary endothelial cell proliferation shows that this test is more sensitive than the yolk sac and that activity in this system can be detected with amounts of ESAF which gave between 2 and $4 \mu \mathrm{g}$ of degraded collagen $/ \mathrm{h}$.

The observation that the low molecular mass angiogenic fraction derived from both oxygen treated and control retinas had demonstratable angiogenic and procollagenase activating activity confirms previous studies on other tissues. ${ }^{11-13}$

Recently 19 it has been suggested that the angiogenic activity in ocular fluids is due to either epidermal or fibroblast growth factor. Although epidermal growth factor (EGF) is angiogenic in vivo and also a mitogen for capillary endothelial cells, it is a totally different entity from the low $M_{r}$ ESAF described in this paper. Firstly, EGF has a molecular mass of 6000 compared with less than 600 for ESAF. Secondly, EGF stimulation of retinal capillary cells is dependent on the cells being plated on to fibronectin coated dishes. ${ }^{20}$ Soluble fibronectin in the media did not elicit this response to EGF, and the cells also failed to respond to EGF when plated on to collagen coated dishes. This is in contrast to the effect of ESAF on retinal capillary cells, which respond and proliferate when grown on a collagen substratum in the absence of fibronectin. ${ }^{21}$ Thirdly, ESAF is not stimulatory to either fibroblast or epidermal cells. Finally, it is worth pointing out that in all cases where ESAF has been detected it has always been of similar molecular mass, ${ }^{12}$ and there is no evidence to suggest that it is a degradation product of any other molecule.

By means of the procollagenase activation assay for ESAF ischaemic kitten retinas were shown to have more than three times the angiogenic activity of the control retinas. Whether hypoxia itself is the vital element linking reduced vascular perfusion with the stimulus to angiogenesis may be questioned. However, even if some other metabolic consequence of ischaemia, such as lactate accumulation, should prove to be involved, the contention that there is a relationship between ischaemia and angiogenesis receives considerable support from our results.

CMT was supported by a grant from the Wellcome Trust.

\section{References}

1 Michaelson IC. The mode of development of the vascular system of the retina, with some observations on its significance for certain retinal diseases. Trans Ophthalmol Soc UK 1948; 68: 137-80.

2 Ashton N, Ward B, Serpell G. Effect of oxygen on developing retinal vessels with particular reference to the problem of retrolental fibroplasia. Br J Ophthalmol 1954; 38: 397-432.

3 Wise GN. Retinal neovascularization. Trans Am Ophthalmol Soc 1956; 54: 729-826.

4 Smith R. Thrombotic glaucoma: a clinico-pathological study. Proc Int XVII Congr Ophthalmol 1954. Montreal, New York: 1955; 2: 1164-75.

5 Ashton N. Retinal vascularization in health and disease. Am J Ophthalmol 1957; 44: 7-17.

6 Smith R. Neovascularisation in ocular disease. Trans Ophthalmol Soc UK 1961; 81: 125-44.

7 Little HL, Rosenthal AR, Dellaporta A, Jacobson DR. The effect of pan-retinal photocoagulation on rubeosis iridis. Am J Ophthalmol 1976; 81: 804-9.

8 Rice TA, Michels RG, Maguire MG, Rice EF. The effect of lensectomy on the incidence of iris neovascularization and neovascular glaucoma after vitrectomy for diabetic retinopathy. Am J Ophthalmol 1983; 95: 1-11.

9 Kissun RD, Garner A. Vasoformative properties of normal and hypoxic retinal tissue. Br J Ophthalmol 1977; 61: 394-8.

10 Kissun RD, Hill CR, Garner A, Phillips P, Kumar S, Weiss JB. A low molecular weight angiogenic factor in cat retina. $\mathrm{Br} J$ Ophthalmol 1982; 66: 165-9.

11 Weiss JB, Brown RA, Kumar S, Phillips P. Tumour angiogenesis factor: a potent low molecular weight compound. Br J Cancer 1979; 40: 493-6. 
$12^{\prime}$ Weiss JB, Elstow SF, Hill CR, et al. Low molecular weight angiogenesis factor: a growth factor not unique to tumours which activates procollagenase. Prog Appl Microcirc 1984; 4: 76-87.

13 Brown RA, Weiss JB, Tomlinson IW, Phillips P, Kumar S. Angiogenic factor from synovial fluid resembling that from tumours. Lancet 1980; i: 682-5.

14 Weiss JB, Hill CR, Davis RJ, McLaughlin B, Sedowofia KA, Brown RA. Activation of a procollagenase by low molecular weight angiogenesis factor. Biosci Rep 1983; 3: 171-7.

15 Baird A, Esch F, Gospodarowitz D. Isolation and structural characterisation of a retinal-derived growth factor for endothelial cells: homologies with fibroblast growth factor. Proc Natl Acad Sci USA in press.

16 Lowry OH, Rosenbrough NJ, Farr AL, Randall RJ. Protein measurement with the Folin phenol reagent. J Biol Chem 1951; 193: $265-75$.
17 Taylor CM, Weiss JB. The chick vitelline membrane as a test system for angiogenesis and antiangiogenesis. Int $J$ Microcirc Clin Exp 1984; 3; 337.

18 Slater TF, Riley PA. Free radical damage in retrolental fibroplasia. Lancet 1970; ii: 467.

19 Baird A, Culler F, Jones KL, Guillemin R. Angiogenic factor in human ocular fluid. Lancet 1985; ii: 563.

20 McAuslan BR, Bender V, Reilly W, Moss BH. New functions of epidermal growth factor: stimulation of capillary endothelial cells migration and matrix dependant proliferation. Cell Biol Int Rep 1985; 9: 175-82.

21 Elstow SF, Schor AM, Weiss JB. Bovine retinal angiogenesis factor is a small molecule. Invest Ophthalmol Vis Sci 1985; 26: 74-9.

Accepted for publication 29 November 1985. 